with further studies. One method already mentioned is a cross matching of national birth and death registers, which should become easier once a computer link exists to allow a detailed comparison of information about subjects listed. Another approach is to use regional obstetric registers or national census data to relate death by suicide to childbirth or child age. These methods are currently being pursued.

If the low risk is confirmed, then more exploration of the possible reasons would be valuable. If there is a large protective effect of motherhood based on concern for the welfare of dependants such concern would be an important focus for suicide prevention work, both with postnatal patients and with others at risk.

This work was made possible by the cooperation of $\mathrm{Dr}$ Elizabeth Cloake, of the Department of Health, and the staff of the Office of Population Censuses and Surveys. Dr Glyn Lewis, of the Institute of Psychiatry, provided statistical advice.

1 Kendell RE, Chalmers JC, Platz C. Epidemiology of puerperal psychoses. Brf Psychiatry 1987;150:662-73.

2 Kumar R, Robson KM. A prospective study of emotional disorders in childbearing women. $B r \mathcal{F}$ Psychiatry 1984;144:35-47.
3 Paffenbarger RS. Epidemiological aspects of parapartum mental illness. British fournal of Preventive and Social Medicine 1964;18:189-95.

+ Watson JP, Elliott SA, Rugg AJ, Brough DI. Psychiatric disorder in pregnancy and the first postnatal year. Br $\mathcal{F} P$ sychiatry 1984;144:453-62.

Kleiner GJ, Greston WM, eds. Suicide in pregnancy. Littleton, Massachusetts: John Wright, 1984

6 Department of Health and Social Security. Report on confidential enquiries into maternal deuths in England and Wales. London: HMSO, 1979, 1982, 1986, 1990. (Triennial publication.

7 Breslow NE, Day NE. Statistical methods in cancer research. Vol 2. The design and analysis of cohort studies. Lyons: International Agency for Research on and analysts of

8 Office of Population Censuses and Surveys. Mortality statistics: cause. London: HMSO, 1974-84. (Annual publication.)

9 O'Hara MW, Zckoski EM. Postpartum depression: a comprehensive review. In: Kumar R, Brockington IF, eds. Motherhood and mental illness. 2. Cause In: Kumar R, Brockington IF, eds. Motherhood
and consequences. London: Wright, 1988:17-63.

10 Cooper PJ, Campbell EA, Day A, Kennerley H, Bond A. Non-psychotic psychiatric disorder after childbirth; a prospective study of prevalence, incidence, course and nature. $B r f$ Psychiatry 1988;152:799-806.

11 Linehan MM, Goodstein JL, Nielsen SL, Chiles JA. Reasons for staying alive when you are thinking of killing yourself: the reasons for the living inventory. F Consult Clin Psychol 1983;51:276-86.

12 Beck AT, Rush J, Shaw BF, Emery G. Cognitive therapy of depression. New York: Guildford Press, 1979.

13 Brockington I, Cox-Roper A. The nosology of puerperal mental illness. In Kumar R, Brockington IF, eds. Motherhood and mental illness. 2. Causes and consequences. London: Wright, 1988:1-16.

14 Office of Population Censuses and Surveys. Birth statistics. London: HMSO, 1973-84. (Annual publication.)

(Accepted 7 September 1990)
Vale of Leven Hospital, Alexandria,

Dunbartonshire G83 0UA

N A Miller, MRCP, clinical research assistant

H A Carmichael, FRCP, consultant physician

F C Hall, BSC, biochemist

Helensburgh,

Dunbartonshire

B D Calder, MRCGP, general

practitioner

University of Glasgow,

Glasgow G12 8QQ

$\mathrm{PO}$ Behan, MD, professor in

neurology

Regional Virus Laboratory, Ruchill Hospital,

Glasgow

E J Bell, MRCPATH, top grade virologist

R A McCartney, FIMLs, chief medical laboratory scientific officer

Correspondence to:

Dr Carmichael.

BMF 1991;302:140-3

\title{
Antibody to coxsackie B virus in diagnosing postviral fatigue syndrome
}

\author{
N A Miller, H A Carmichael, B D Calder, P O Behan, E J Bell, R A McCartney, F C Hall
}

\section{Abstract}

Objective-To study the association between coxsackie $B$ virus infection and the postviral fatigue syndrome and to assess the immunological abnormalities associated with the syndrome.

Design-Case-control study of patients with the postviral fatigue syndrome referred by local general practitioners over one year.

Setting-General practitioner referrals in Dunbartonshire, Scotland.

Patients - 254 Patients referred with the postviral fatigue syndrome (exhaustion, myalgia, and other symptoms referable to postviral fatigue syndrome of fairly recent onset-that is, several months) and age and sex matched controls obtained from same general practitioner; 11 patients were rejected because of wrong diagnoses, resolution of symptoms, and refusal to participate, leaving 243 patients and matched controls.

Main outcome measures-Detailed questionnaire (patients and controls) and clinical examination (patients) and blind analysis of blood sample at entry and after six months for determination of coxsackie $B$ virus IgM and IgG antibodies and other variables (including lymphocyte protein synthesis, lymphocyte subsets, and immune complexes).

Results-Percentage positive rates for coxsackie $B$ virus IgM at entry were $24.4 \%$ for patients and $22.6 \%$ for controls and for coxsackie $B$ virus IgG $56.2 \%$ and $55.3 \%$ respectively; there were no significant differences between different categories of patients according to clinical likelihood of the syndrome nor any predictive value in a fourfold rise or fall in the coxsackie $B$ virus IgG titre in patients between entry and review at six months. The rates of positive antibody test results in patients and controls showed a strong seasonal variation. Of the numerous immunological tests performed, only a few detected significant abnormalities; in particular the mean value for immune complex concentration was much higher in $\mathbf{3 5}$ patients and 35 controls compared with the normal range and mean value for total IgM was also raised in 227 patients and 35 controls compared with the normal range.

Conclusions-Serological tests available for detecting coxsackie $B$ virus antibodies do not help diagnose the postviral fatigue syndrome. Percentage positive rates of the antibodies in patients simply reflect the background in the population as probably do the raised concentrations of total IgM and immune complexes.

\section{Introduction}

Since 1934 numerous outbreaks of a curious ill defined illness showing similarities in presentation, clinical picture, and outcome have been reported throughout the world under various synonyms, the most recent being the postviral fatigue syndrome and the chronic fatigue syndrome. ${ }^{1-4}$ Outbreaks of the illness have been associated with increased antibody titres to coxsackie B virus. ${ }^{5-9}$ One of us (HC) noted that between 1980 and 1984 the annual referral rate of medical outpatients in Dumbarton district thought to have the postviral fatigue syndrome more than quadrupled and seemed to be associated with high positive rates of coxsackie B IgG antibodies (about $40 \%$ each year) compared with the previously reported background rate of positive tests. ${ }^{10} \mathrm{With}$ the advent of a coxsackie $B$ virus $\operatorname{IgM}$ antibody test the present prospective trial was set up to assess any association between the postvirual fatigue syndrome and coxsackie $B$ virus infection and to examine immunological abnormalities previously described in this syndrome. ${ }^{8}$

\section{Materials and methods}

Patients and controls

During one year starting on 1 May 1985 local general practitioners were asked to refer patients with 
the postviral fatigue syndrome, the guidelines being exhaustion for about six months at least with symptoms from the other main groupings (muscle, psychological, cognitive, autonomic, neurological, and cardiological). A matched control was obtained from the referring practitioner's list by taking the next surname after that of the patient and choosing the first subsequent entry for a patient with the same sex and for which the age was within $10 \%$ of that of the referred patient.

\section{Clinical assessment}

One doctor (NM) completed a detailed questionnaire and examination for each patient and graded the certainty of diagnosis of the post viral fatigue syndrome as follows: category 1, "classic" (acute, viral type onset, other diagnosis very unlikely); category 2, very probable (other diagnosis unlikely); category 3, possible (some doubt); category 4, least likely (nonspecific presentation, adverse social or psychological factors).

A total of 243 patients were entered into the study. Eleven were rejected because of wrong diagnoses, resolution of symptoms, refusal to participate, etc. There were $177(73 \%)$ women (mean age 37 ) and 66 $(27 \%)$ men (mean age 36$)$. On entry to the study the controls completed the same questionnaire as the patients but without quantifying symptoms.

\section{Laboratory investigations}

Blood obtained from patients and matched controls (usually within one month of each other) was tested blind for coxsackie virus $\operatorname{Ig} M$ antibodies using the mu-antibody-capture enzyme linked immunosorbent assay (ELISA) test ${ }^{11}$ and for coxsackie B virus IgG neutralising antibodies with the micrometabolic inhibition method,,$^{12}$ at entry and after six months. A full blood count, renal and hepatic function tests, and virological screen were done in all patients at entry.

\section{Immunological studies}

In vitro peripheral blood lymphocyte protein synthesis, lymphocyte subset analysis, and immune complexes $^{8}$ were determined in 35 randomly selected patients and 35 controls as well as immunoglobulin estimations in the 35 controls and 227 study patients.

\section{Statistical methods}

The results of coxsackie $B$ virus serological testing in 217 patients and matched controls were analysed with McNemar's test for matched samples and subgroup analysis with the $\chi^{2}$ test for trend. The immunological results were analysed with the $t$ distribution for means for each investigation with the Bonferroni correction for multiple comparisons.

\section{Results}

The pattern of symptoms was similar in coxsackie B virus IgM positive and IgM negative patients (table I). There was no significant difference in the clinical outcome at six months' review between patients with a fourfold rise or a fourfold fall in the coxsackie B virus IgG titre between entry and review (table II).

TABLE I-Clinical picture for patients at entry who were negative and positive for coxsackie B virus IgM

\begin{tabular}{|c|c|c|c|c|c|c|c|c|}
\hline Symptom & $\begin{array}{l}\% \text { Negative } \\
\text { for IgM }\end{array}$ & $\begin{array}{l}\% \text { Positive } \\
\text { for IgM }\end{array}$ & Symptom & $\begin{array}{l}\% \text { Negative } \\
\text { for IgM }\end{array}$ & $\begin{array}{l}\% \text { Positive } \\
\text { for IgM }\end{array}$ & Symptom & $\begin{array}{l}\% \text { Negative } \\
\text { for IgM }\end{array}$ & $\begin{array}{c}\text { \% Positive } \\
\text { for } \operatorname{Ig} M\end{array}$ \\
\hline Exhaustion & 100 & 100 & Poor memory & 58 & 41 & Disturbed micturition & 34 & 31 \\
\hline Malaise & 98 & 98 & Insomnia & 57 & 47 & Depersonalisation & 34 & 27 \\
\hline Tiredness & 85 & 85 & Cold sensitivity & 55 & 56 & Diarrhoea & 32 & 25 \\
\hline Muscle fatigue & 62 & 81 & Nausea & 45 & 56 & Abdominal pain & 30 & 31 \\
\hline Headache & 73 & 78 & Dizziness & 55 & 54 & Panic attacks & 30 & 31 \\
\hline Poor concentration & 74 & 64 & Palpitations & 49 & 54 & Vertigo & 27 & 24 \\
\hline Sweating & 72 & 71 & Paraesthesiae & 50 & 51 & Numbness & 23 & 25 \\
\hline Flushing & 65 & 68 & Sore eyes & 49 & 44 & Tinnitus & 23 & 17 \\
\hline Chest pain & 66 & 47 & Sore throat & 47 & 42 & Muscle cramp & 20 & 19 \\
\hline Anxiety & 61 & 64 & Arthralgia & 43 & 46 & Sore ears & 20 & 17 \\
\hline Depression & 61 & 63 & Tight bands & 44 & 42 & Ataxia & 14 & 14 \\
\hline Breathlessness & 52 & 61 & Abdominal distension & 31 & 41 & Vomiting & 11 & 14 \\
\hline Emotional lability & 59 & 53 & Faintness & 28 & 37 & Facial pain & 12 & 10 \\
\hline Anomia & 59 & 44 & Anorexia & 35 & 34 & & & \\
\hline Muscle pain & 51 & 58 & Blurred vision & 35 & 27 & & & \\
\hline
\end{tabular}

TABLE II-Clinical change in patients with fourfold rise or fall in coxsackie B virus IgG titre between entry and six months' review

\begin{tabular}{lccc}
\hline Change in titre & No of patients & $\begin{array}{c}\text { No (\%) clinically } \\
\text { improved }\end{array}$ & unchanged \\
\hline Fourfold fall & 31 & $24(77)$ & $7(23)$ \\
Fourfold rise & 26 & $22(85)$ & $4(15)$ \\
\hline
\end{tabular}

At entry, although the percentage of positive rates for coxsackie $B$ virus antibodies were high, there were no significant differences between 217 patients and their matched controls with positive results in 53 $(24 \cdot 4 \%)$ and $49(22.6 \%)$ respectively for $\operatorname{IgM}, 122$ $(56 \cdot 2 \%)$ and $120(55 \cdot 3 \%)$ respectively for $\mathrm{IgG}$, and 55 $(25 \cdot 4 \%)$ and $50(23 \cdot 0 \%)$ respectively for IgG titre $\geqslant 512$

TABLE III-Analysis of coxsackie B virus IgM and IgG in total sample (217 patients and matched controls at entry and six months and by subgroup at entry visit

\begin{tabular}{|c|c|c|c|c|c|c|}
\hline & \multicolumn{2}{|r|}{$\operatorname{Ig} M$ positive } & \multicolumn{2}{|r|}{ IgG positive } & \multicolumn{2}{|r|}{ IgG titre $\geqslant 512$} \\
\hline & No & $\begin{array}{c}\% \text { Positive } \\
(95 \% \text { confidence interval })\end{array}$ & No & $\begin{array}{c}\% \text { Positive } \\
\text { ( } 95 \% \text { confidence interval) } \\
\end{array}$ & No & $\begin{array}{c}\% \text { Positive } \\
\text { (95\% confidence interval) }\end{array}$ \\
\hline \multicolumn{7}{|c|}{ Total sample (McNemar's test for matched samples) } \\
\hline At entry / patients 53 & & $24 \cdot 4^{\star}(18 \cdot 7$ to $30 \cdot 1)$ & 122 & $56 \cdot 2(49 \cdot 6$ to $62 \cdot 8)$ & 55 & $25 \cdot 4(19 \cdot 6$ to $31 \cdot 1)$ \\
\hline | controls & 49 & $22 \cdot 6(17 \cdot 0$ to $28 \cdot 1)$ & 120 & $55.3(48.7$ to 61.9$)$ & 50 & $23 \cdot 0(17 \cdot 4$ to $28 \cdot 6)$ \\
\hline At review $\left\{\begin{array}{l}\text { patients } \\
\text { controls }\end{array}\right.$ & $\begin{array}{l}29 \\
36\end{array}$ & $\begin{array}{l}13.4^{\star}(8.8 \text { to } 17.9) \\
16.6(11.6 \text { to } 21.5)\end{array}$ & $\begin{array}{l}127 \\
137\end{array}$ & $\begin{array}{l}58 \cdot 5(52 \cdot 0 \text { to } 65 \cdot 1) \\
63 \cdot 1(56 \cdot 7 \text { to } 69 \cdot 6)\end{array}$ & $\begin{array}{l}51 \\
55\end{array}$ & $\begin{array}{l}23 \cdot 5(17 \cdot 9 \text { to } 29 \cdot 1) \\
25 \cdot 4(19 \cdot 6 \text { to } 31 \cdot 1)\end{array}$ \\
\hline \multirow{2}{*}{\multicolumn{7}{|c|}{ Subgroup analysis at entry visit ( $\chi^{2}$ for trend) }} \\
\hline & & & & & & \\
\hline Category $\mathbf{l}(\mathbf{n}=81)$ & 22 & $27 \cdot 2(17 \cdot 5$ to $36 \cdot 9)$ & 40 & $49 \cdot 4(38 \cdot 5$ to $60 \cdot 3)$ & 17 & $21 \cdot 0(12 \cdot 1$ to $29 \cdot 9)$ \\
\hline Category $2(\mathrm{n}=92)$ & 21 & $22 \cdot 8(14 \cdot 2$ to $31 \cdot 4)$ & 59 & $64 \cdot 1(34.3$ to 73.9$)$ & 28 & $30 \cdot 4(21 \cdot 0$ to $39 \cdot 8)$ \\
\hline Categories 3 and $4(n=56)$ & 12 & $21 \cdot 4(10 \cdot 7$ to $32 \cdot 1)$ & 30 & $53 \cdot 6(40 \cdot 5$ to $66 \cdot 7)$ & 13 & $23 \cdot 2(12 \cdot 1$ to $34 \cdot 3)$ \\
\hline \multicolumn{7}{|l|}{ Controls: } \\
\hline With 0-1 symptoms $(n=74)$ & 18 & $24 \cdot 3(14 \cdot 5$ to $34 \cdot 1)$ & 41 & $55 \cdot 4(44 \cdot 1$ to $66 \cdot 7)$ & 23 & $31 \cdot 1(20 \cdot 6$ to $41 \cdot 6)$ \\
\hline With 2-8 symptoms $(\mathbf{n}=99)$ & 20 & $20 \cdot 2(12 \cdot 3$ to $28 \cdot 1)$ & 44 & $44 \cdot 4(34 \cdot 6$ to $54 \cdot 2)$ & 12 & $12 \cdot 1(5 \cdot 7$ to $18 \cdot 5)$ \\
\hline With $>8$ symptoms $(n=70)$ & 17 & $24 \cdot 3(14 \cdot 3$ to $34 \cdot 3)$ & .46 & $65 \cdot 7(54 \cdot 6$ to $76 \cdot 8)$ & 22 & $31 \cdot 4(20 \cdot 5$ to $42 \cdot 3)$ \\
\hline
\end{tabular}

${ }^{\star} \mathrm{p}<0 \cdot 001$ 
TABLE IV - Results of immunological testing in patients and controls compared with normal values. Unless otherwise stated values are means $(S D)$, analysed by the $t$ distribution for means with Bonferroni correction for multiple comparisons and using logarithmic transformation when appropriate ${ }^{\star}$

\begin{tabular}{|c|c|c|c|c|c|}
\hline \multirow[b]{2}{*}{ Variable } & \multirow[b]{2}{*}{$\begin{array}{l}\text { Normal } \\
\text { value }\end{array}$} & \multirow[b]{2}{*}{ Controls } & \multicolumn{2}{|c|}{ Patients } & \multirow[b]{2}{*}{ Significance } \\
\hline & & & $\begin{array}{c}\text { With } \\
\text { acute } \\
\text { conditions } \\
(<6 / 12 \text { months })\end{array}$ & $\begin{array}{c}\text { With } \\
\text { chronic } \\
\text { conditions } \\
(>6 / 12 \text { months })\end{array}$ & \\
\hline \multicolumn{2}{|c|}{$\begin{array}{l}\text { No of patients } \\
\text { T cells \% reactive with monoclonal antibody: }\end{array}$} & 35 & 15 & 20 & \\
\hline $\begin{array}{l}\text { Tt } \\
\text { Th } \\
\text { Ts }\end{array}$ & $\begin{array}{l}71(6 \cdot 4) \\
48(3 \cdot 9) \\
23(5 \cdot 4)\end{array}$ & $\begin{array}{l}69 \cdot 3(8 \cdot 3) \\
45 \cdot 4(8 \cdot 7) \\
23 \cdot 8(6 \cdot 9)\end{array}$ & $\begin{array}{l}74 \cdot 9(7 \cdot 9) \\
49 \cdot 6(12 \cdot 0) \\
21 \cdot 3(7 \cdot 2)\end{array}$ & $\begin{array}{l}68.5(9 \cdot 0) \\
47 \cdot 5(9 \cdot 8) \\
21 \cdot 0(5 \cdot 8)\end{array}$ & \\
\hline B & $11(3 \cdot 9)^{\lambda}$ & $11 \cdot 5(4 \cdot 9)^{\mathrm{B}}$ & $7 \cdot 7(2 \cdot 6)^{A B}$ & $9 \cdot 0(4 \cdot 4)$ & $\begin{array}{l}\mathrm{A}(6) \mathrm{p}<0.05 \\
\mathrm{~B}(6) \mathrm{p}<0.01\end{array}$ \\
\hline $\begin{array}{l}\text { NK } \\
\text { Th/Ts } \\
\text { Lymphocyte protein synthesi } \\
\text { (maximum stimulation inde }\end{array}$ & $\begin{array}{l}10(5 \cdot 3) \\
2 \cdot 3(0 \cdot 75) \\
\text { ex) }\end{array}$ & $\begin{array}{c}11 \cdot 0(6 \cdot 4)^{c} \\
2 \cdot 2(1 \cdot 3)\end{array}$ & $\begin{array}{l}7 \cdot 1(3.6)^{c} \\
2 \cdot 7(1.5)\end{array}$ & $\begin{array}{r}11 \cdot 2(6 \cdot 2) \\
2 \cdot 5(1 \cdot 1)\end{array}$ & $C(6) p<0.05$ \\
\hline Complement: & $2.4(0.36)^{\mathrm{D}}$ & $2 \cdot 0(0 \cdot 40)^{\mathrm{D}}$ & $2 \cdot 1(0 \cdot 48)$ & $2 \cdot 1(0.45)$ & $\mathrm{D}(6) \mathrm{p}<0.01$ \\
\hline $\begin{array}{l}\text { Clq }(\% \text { of normal human } \\
\text { serum }) \\
\text { C3c }(g / l) \\
\text { C4 }(g / l)\end{array}$ & $\begin{array}{l}70-140 \\
500-1200 \\
220-560\end{array}$ & $\begin{array}{r}107(21)^{\mathrm{E}} \\
1030(340) \\
434(240)\end{array}$ & $\begin{array}{r}92(24) \\
1120(270) \\
520(310)\end{array}$ & $\begin{array}{l}90(21)^{\mathrm{E}} \\
960(260) \\
380(170)\end{array}$ & $E(6) p<0.05$ \\
\hline $\begin{array}{l}\text { C3 proactivator (\% normal } \\
\text { human serum) } \\
\text { Immune complex }(\mathrm{g} / \mathrm{l})^{\star}\end{array}$ & $\begin{array}{l}80-160 \\
39(20)^{F(i H}\end{array}$ & $\begin{array}{r}96 \cdot 4(24) \\
114(112)^{F}\end{array}$ & $\begin{array}{c}91(24) \\
126(108)^{\mathrm{G}}\end{array}$ & $\begin{array}{r}84 \cdot 1(16) \\
114(98)^{\mathrm{H}}\end{array}$ & $\begin{array}{l}F(6) p<0.006 \\
G(6) p<0.006 \\
H(6) p<0.006\end{array}$ \\
\hline $\begin{array}{l}\text { IgM estimation: } \\
\text { No of women } \\
\text { Mean IgM }(g / l) \\
\text { No of men } \\
\text { Mean IgM }(g / l)\end{array}$ & $\begin{array}{l}88 \\
160(62)^{\mathrm{I}} \\
62 \\
125(53)^{\mathrm{KL}}\end{array}$ & $\begin{array}{l}26 \\
275(89)^{1} \\
9 \\
243(99)^{k}\end{array}$ & $\begin{array}{r}168 \\
256 \\
59 \\
206\end{array}$ & $\begin{array}{l}8 \\
6(117)^{4} \\
9 \\
6(87)^{L}\end{array}$ & $\begin{array}{l}\mathrm{I}(6) \mathrm{p}<0.003 \\
\mathrm{~J}(6) \mathrm{p}<0.003 \\
\mathrm{~K}(6) \mathrm{p}<0.003 \\
\mathrm{~L}(6) \mathrm{p}<0.003\end{array}$ \\
\hline
\end{tabular}
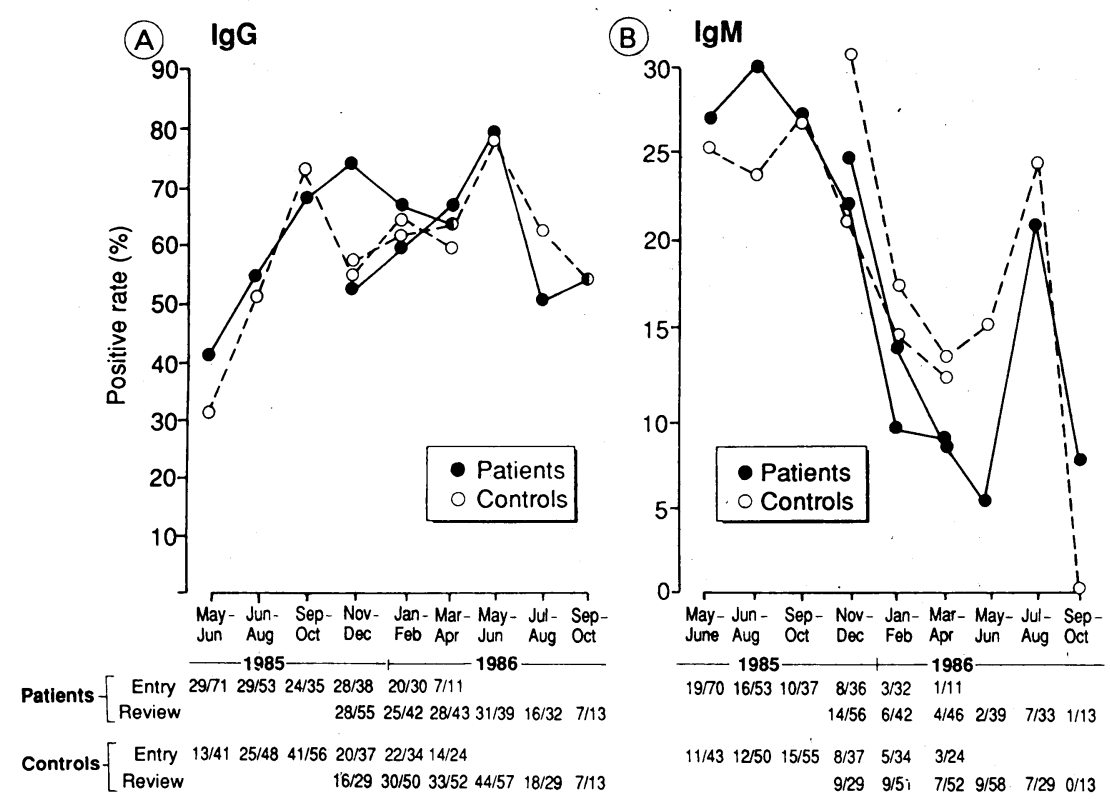

Bimonthly percentage positive rates for coxsackie $B$ virus antibody in patients and controls at entry and review, May 1985-October 1986 (A) IgG; (B) IgM

(table III). Similar findings were found by subgroup analysis at entry (table III). The significant fall in the percentage rates for coxsackie B virus IgM in patients between entry and review is probably explained by the strong seasonal variation in rates for both patients and controls, as the figure suggests.

Patients and controls had significantly higher values for immune complex concentration than the normal value (table IV). Although values for lymphocyte protein synthesis were reduced in the patients and controls compared with normal values, the difference only reached significance in the controls. In patients with the acute condition there was a significant reduction in values for B lymphocytes compared with those for controls and normal values and in values for NK lymphocytes in comparison with those for controls. There was a small but significant reduction in the Clq complement component in patients with the chronic condition compared with that in controls. Although there was no difference in total IgM between the patients and controls, there was a highly significant increase in total IgM concentration in patients and controls in comparison with the normal range (among women 256 (SD 117), 275 (89), and 160 (62) respectively and among men $206(87), 243(99)$, and $125(53)$ respectively (table IV).

\section{Discussion}

The nature, clinical picture, and diagnosis of the postviral fatigue syndrome have been matters of unresolved debate for many decades, made worse by lack of an accepted diagnostic marker. Access to specialist electrophysiology ${ }^{13}$ and magnetic resonance imaging ${ }^{14}$ may not be available or even appropriate.

Although there has been much interest and discussion regarding the role of immune dysfunction in the aetiology of the postviral fatigue syndrome, few consistent immunological abnormalities have been reported. Reports have included abnormal circulating lymphocytes and depressed lymphocyte function with impaired cytotoxic $T$ cell responses to specific virus epitopes, ${ }^{15}$ increased or decreased immunoglobulin concentrations, ${ }^{16}$ immune complexes containing coxsackie $B$ virus antigen, ${ }^{17}$ and normal and abnormal suppressor and inducer T cell counts. ${ }^{16}{ }^{18}$ Until now, no reports of reduced B and NK cell counts have been published. Discrepancies in lymphocyte subpopulations seen in different studies are also found in other disease states such as multiple sclerosis ${ }^{19}$ and may reflect differences in technique, selection of patients, and sampling criteria. Although not specifically designed to investigate the role of immune dysfunction in the aetiology of the postviral fatigue syndrome, our study does throw some doubt on the usefulness of these immunological variables in diagnosing this condition in so far as individual controls often had appreciably abnormal results of one or more of the immunological variables, including $T$ cell subsets, protein synthesis, and complement concentrations. In particular, the raised immune complex and total IgM concentrations found in this study may simply reflect the background exposure of the population to coxsackie B virus. An association between coxsackie $B$ virus infection and the postviral fatigue syndrome has been noted in some studies ${ }^{5.9}$ but not others, ${ }^{2021}$ and other causative agents have been incriminated in yet other studies. ${ }^{15} 161822-25$

Newer tests for coxsackie B virus infection are being developed. Yousef $e t a l$ report higher positive results in patients with the postviral fatigue syndrome than in controls with a new method for isolating coxsackie $B$ virus from stool samples and also with a new enterovirus specific antigen test as well as coxsackie $B$ virus IgM antibodies. ${ }^{26}$ Evidence of enterovirus specific RNA in skeletal muscle hiopsies was shown in 20 out of 96 patients with the postviral fatigue syndrome ${ }^{27}$ and Epstein-Barr virus DNA was identified in other cases. $^{28}$

Coxsackie $B$ virus infection is common and asymptomatic in most people. Positive serological results for coxsackie $B$ virus simply reflect exposure to the virus and do not imply ill health or necessarily explain ill health. Our experience shows that the currently available serological tests for coxsackie B virus $\operatorname{IgM}$ and IgG do not help to distinguish patients with the postviral fatigue syndrome from the normal population. Future studies using established or newly developed laboratory tests must take account of the need for properly matched controls from the same geographical area studied at the same time. Such studies must also try to deal with the question of whether a positive result simply implies exposure to the virus or a cause of chronic continuing ill health.

We thank Argyll and Clyde Health Board for funding this trial and, in particular, Dr A Reid for his help in initiating the 
trial and Dr E MacPherson in helping to set it up; Professor $M$ Timbury for help in setting up the study and in the study group meetings; Nurse A McLaren and Mrs J Duncan for running the study; and Miss $\mathrm{H}$ Ganson for computerising and collating the study results and Mrs C Spy and Miss T Spence for their secretarial help. We also thank the local general practitioners for their cooperation in referring patients to the study.

1 Acheson ED. The clinical syndrome variously called benign myalgic encephalomyelitis, Iceland disease and epidemic neuromyasthenia. Am f Med 1959;26:569-95.

2 Henderson DA, Shelokov A. Epidemic neuromyasthenia-clinical syndrome? N Engl f Med 1959;260:757-64, 814-8.

3 Ramsay AM. Postviral fatigue syndrome: the saga of Royal Free disease. London: Gower, 1986

4 Behan PO, Behan WMH. Postviral fatigue syndrome. CRC Critical Reviews in Clinical Neurobiology 1988;4:157-78.

5 Fegan KG, Behan PO, Bell EJ. Myalgic encephalomyelitis-report of an epidemic. $f R$ Coll Gen Pract 1983;33:335-7.

6 Keighley BD, Bell EJ. Sporadic myalgic encephalomyelitis in a rural practice. F R Coll Gen Pract 1983;33:339-41.

7 Calder BD, Warnock PJ. Coxsackie B infection in a Scottish general practice. $\mathcal{F} R$ Coll Gen Pract 1984;34:15-9.

practice. $\mathcal{F} R$ Coll Gen Pract 1984;34:15-9. analysis of the findings in 50 cases. F Infect 1985;10:211-22.

9 Calder BD, Warnock PJ, McCartney RA, Bell EJ. Coxsackie B viruses and postviral syndrome: a prospective study in general practice. and postviral syndrome: a prospect
$7 R$ Coll Gen Pract 1987;37:11-4.

10 Bell EJ, Irvine KG, Gardiner AJS, Rodger JC. Coxsackie B infection in a general medical unit. Scott Med f 1983;28:157-9.

11 Grist NR, Bell EJ, Follett EA, et al. Diagnostic methods in clinical virology. Oxford: Blackwell, 1979.

12 McCartney RA, Banatgala JE, Bell EJ. Routine use of mu-antibody capture ELISA for the serological diagnosis of coxsackie virus infections. $\mathcal{F}$ Med Virol 1986;19:205-12.

13 Jamal GA, Hansen S. Electrophysiological studies in the postvira fatigue syndrome. $\mathcal{F}$ Neurol Neurosurg Psychiatry 1985;48:691-4.

14 Arnold DL, Bore PJ, Radda GK, Styles P, Taylor DJ. Excessive intracellular acidosis of skeletal muscle on exercise in a patient with postviral exhaustion/fatigue syndrome. Lancet 1984;i:1367-9.

15 Borysiewicz LK, Haworth SJ, Cohen J, Mundin J, Rickinson A,
Sissona JCP. Epstein-Barr virus-specific immune defects in patients with persistent symptoms following infectious mononucleosis. $Q \mathcal{F}$ Med 1986;58:111-21.

16 Strauss SE, Tosato G, Armstrong G, et al. Persisting illness and fatigue in adults with evidence of Epstein-Barr virus infection. Ann Intern Med 1985;102:7-16

17 Al Kadiry W, Gold RG, Behan PO, Mowbray JF. Analysis of antigens in the circulating immune complexes of patients with coxsackie infections. In: Behan PO, Meulen VT, Rose FC, eds. Immunology of nervous system infections. Holland: Elsevier, 1983:61-7. (Progress in brain research; vol 59 .

18 Hamblin TJ, Hussain J, Akbar An, Tang YC, Smith JL, Jones DB. Immunological reason for chronic ill health after infectious mononucleosis. BMF 1983;287:85-8.

19 Rice GP, Finney DA, Braheny SL, Knobler RL, Sipe JC, Oldstone MB Disease activity markers in multiple sclerosis. $\mathcal{f}$ Neuroimmuno 1984;6:75-84.

20 Dillon MJ, Marshall WC, Dudgeon JA, Steigman AJ. Epidemic neuromyasthenia outbreak among nurses at a children's hospital. $B M \mathcal{F} 1974 ; \mathrm{i}: 301-5$.

21 Poole M, Snow P, Paul C. An unexplained illness in West Otago. $N Z$ Med f 1984;97:351-4.

22 Tobi M, Morag A, Ravid Z, et al. Prolonged atypical infection associated with serological evidence of Epstein-Barr virus infection. Lance $1982 ; \mathrm{i}: 61-4$

23 Dubois RE, Seeley JK, Brus I, et al. Chronic mononucleosis syndrome. South Med F 1984;77:1376-82.

24 Jones JF, Ray G, Minnich LL, Hicks MJ, Kibler R, Lucas D. Evidence for active Epstein-Barr infection in patients with persistent unfor active Epstein-Barr infection in patients with persistent unMed 1985;102:1-7.

25 Barnes D. Mystery disease at Lake Tahoe challenges virologists and clinicians. Science 1986;234:541-4

26 Yousef GE, Bell EJ, Mann GF, et al. Chronic enterovirus infection in patients with postviral fatigue syndrome. Lancet 1988; i:146-50.

27 Archard LC, Bowles NE, Behan PO, Bell EJ, Doyle D. Postviral fatigue syndrome: persistence of enterovirus RNA in muscle and elevated creatine kinase. $\mathcal{F} R$ Soc Med 1988;81:326-9.

28 Archard LC, Peters J, Behan PO, Doyle D, Bowles NE. Detection of Epstein-Barr virus DNA in muscle with the postviral fatigue syndrome, myalgic encephalomyelitis. Fournal of Experimental Clinical Cancer Research 1988;7:3.

(Accepted 1 November 1990)
Centre for Public Health

Research, S-65182

Karlstad, Sweden

Gunnar Lindberg, MD, senior

physician

Department of Cancer

Epidemiology,

Radiumhemmet,

Karolinska Hospital,

Stockholm, Sweden

Gunnar A Eklund, PHD,

professor of epidemiology

\section{Department of}

Community Health

Sciences, University of

Lund, Malmö, Sweden

Bo Gullberg, MA, senior

lecturer in medical statistics

Lennart Råstam, $M D$, senior

lecturer in family medicine

Correspondence and requests for reprints to:

Dr Lindberg.

BMF 1991;302:143-6

\title{
Serum sialic acid concentration and cardiovascular mortality
}

\author{
Gunnar Lindberg, Gunnar A Eklund, Bo Gullberg, Lennart Råstam
}

\section{Abstract}

Objective-To determine whether serum sialic acid concentration may be used to predict short and long term cardiovascular mortality.

Design-Prospective study on all men and women who had their serum sialic acid concentration measured as part of a general health survey in 1964 or in 1965. All were followed up for an average of 20.5 years.

Setting-Geographical part of the county of Värmland, Sweden.

Subjects-Residents in the area participating in a health check up in 1964-5 (27065 men and 28037 women), of whom 372 men ( 169 with incomplete data and 203 lost to follow up) and 345 women (143 and 202 respectively) were excluded; thus 26693 men and 27692 women entered the study. The study sample was restricted to subjects aged 40-74 during any of the 20 years' follow up.

Main outcome measures-Serum sialic acid concentration, serum cholesterol concentration, diastolic blood pressure, body mass index at the general health survey visit; cardiovascular and noncardiovascular deaths during three periods of follow up (0-6 years, 7-13 years, and 14-20 years), according to the Swedish mortality register, in subjects aged 45-74.

Results-Mean serum sialic acid concentration $(\mathrm{mg} / 100 \mathrm{ml})$ was 68.8 (SD 8.0) for men and 69.2 (8.0) for women; the average concentration increasing with age in both sexes. A total of $5639(21 \%)$ men and $3307(12 \%)$ women died during the follow up period, in whom death in $3052(54 \%)$ men and $1368(41 \%)$ women was from cardiovascular causes. During short (0-6 years), medium (7-13 years), and long (14-20 years) term follow up the relative risk of death from cardiovascular disease increased with increasing serum sialic acid concentration. The relative risk $(95 \%$ confidence interval) associated with the highest quartile of sialic acid concentration compared with the lowest quartile was $2.38(2.01$ to $2.83)$ in men and $2.62(1.93$ to 3.57$)$ in women. Similar results were found for deaths from noncardiovascular disease with relative risks of 1.50 $(1.34$ to 2.68$)$ in men and $1.89(1.57$ to 2.28$)$ in women, but these relative risks were significantly lower than those for deaths from cardiovascular disease $(p<0.001$ and $p<0.005$ respectively). In multivariate analysis of total mortality and of cardiovascular mortality with sialic acid concentration, serum cholesterol concentration, diastolic blood pressure, and body mass index as independent variables the impact of sialic acid concentration was virtually the same as in univariate analysis.

Conclusion-Serum sialic acid concentration is a strong predictor of cardiovascular mortality. A possible explanation of these findings is that the serum sialic acid concentration may reflect the existence or the activity of an atherosclerotic process, and this may warrant further investigation.

\section{Introduction}

Sialic acid, a family of acetylated derivatives of neuraminic acid, is widely distributed in mammals. It usually occurs as a terminal component at the nonreducing end of carbohydrate chains of glycoproteins 